\title{
Review of the conference Dante and Music
}

University of Pennsylvania, Philadelphia, 5-6 November 2015.

Francesco Ciabattoni

Georgetown University

fc237@georgetown.edu

\section{(a) (1)}

n 5-6 November 20I5, the University of Pennsylvania hosted a conference the theme of which was Dante and Music. The organizers--Kevin Brownlee, Mauro Calcagno, Marina Della Putta Johnston and Fabio Finotti-drew many fine scholars together from different disciplines, creating an excellent occasion for intellectual exchange and growth.

Professor Kevin Brownlee opened the day with "Explicit Song and Cited Scripture in the Commedia: Five Key Examples", analyzing the function of musical progress of the songs in Pg. XXVII, 6-63, 29.I-5I, Pd. VIII, 25-39, Pd. XXIII, 94-III and in Pd. XXXII, 94-99. Focusing on the modes of representation and performance, Brownlee revealed the meaning in the Commedia of the musical psalms, Charles Martel's quotation of Dante's own Voi che 'ntendendo and Gabriel's circular song to the Virgin.

In "Dante Decrypted: musica universalis in the Textual Architecture of the Commedia," Catherine Adoyo created a model of the poem's comprehensive architecture founded on musico-mathematical data that shows the formal design of Dante's poem. Exploring the association between Beatrice and the number nine, the paper demonstrated the Commedia's textual architecture, and both the physical and metaphysical concepts of Ptolemaic cosmology rooted in musica mundana.

Helena Phillips-Robins argued in “[L]or compatire a me': Singing for Dante in Purgatorio XXX-XXXI" that the performance of Psalm 30 in Pg. $\mathrm{XXX}, 82-99$ triggers a spiritual transformation in the pilgrim, melting his frozen fears into contrition. The angels' singing plays a key role in this process, and Phillips-Robins reveals the important connection between music and its social aspects: an audience (the angels but also the readers of the Commedia) is necessary to a performance. Because the angels stop short of "Miserere mei", the readers of $P g$. XXX-XXXI are prompted to mentally perform "Miserere mei" as a latent song in the Earthly Paradise.

"Stasis and carnal song: the Hag-siren of Purgatorio XIX" by Fiorentina Russo explored the patristic and medieval traditions of the siren as a figure 
for the negative effects of music on the soul, casting her as a more tempting version of the Medusa of If. IX. Russo connected the sexualized voice of the siren to the sexually charged rime petrose of Dante's earlier production.

Martin Eisner ("Dante's Song: Reconsidering the Significance of "Amor che ne la mente mi ragiona" in Purgatorio II") challenged the critical claim that the musical performance of "Amor che ne la mente mi ragiona" in $P g$. II should be seen as a censoring of the Convivio. Drawing evidence from the Virgilian and Boethian tradition of using songs as a way of reinforcing a past experience, Eisner argues that Casella's song is in fact a reflection on the ontology of poetry and the authority of the poet.

In "Sound Production and the Soul," Alison Cornish investigated the notion of sound's evanescence. As something that is alive but immaterial, sound disturbs matter by breaking the air. Voice, a particular sub-category of sound, possesses breath and blood, and Dante often calls attention to the anatomic mechanics of voice emission as well as to its realistic auditory details (from the spluttering trees of the suicides to the flickering speech of the fraudulent counselors who burn in flames, to the mysterious voice(s) intoning "Te Deum" at the gates of purgatory, to the conglomerate voice of the eagle in the heaven of Jupiter). Cornish frames her critical discussion with Aristotle's De anima, in which the physics and acoustics of sound production explain the dynamics of words and sound that make up vocal music.

Francesco Ciabattoni ("The Sweet Roar of Thunder") showed the historical-musicological context of the lemma "organi" / "organo" as it appears in Pg. IX, I44 and Pd. XVII, 44. Drawing from medieval treatises and monks' descriptions such as Raban Maur, Notkerus Balbulus, Baldric of Dol, Aelred of Rievaulx and Wulstan, Ciabattoni demonstrated that Pg. IX, I44 ("quando a cantar con organi si stea") evokes a great pipe organ as was found in some medieval churches. Ciabattoni also argued that Pd. XVII, 43-44 ("come viene ad orecchia / dolce armonia da organo") should be understood as a polyphonic organum that serves the twofold purpose of lending authority to the Commedia's longest prophecy and of musically representing the harmonious reconciliation of life's highs and lows.

In "Song(s) of Songs: Musical Genres in the Divine Comedy," Andrés Amitai Wilson proposed that the music of the spheres begins in the ineffable space where speech ends. Wilson investigated Dante's ontological understanding of music and the connections between the Commedia and various medieval music genres, paying particular attention to the Book of Psalms and the Song of Songs, in order to show the elastic boundary between speech and music that Dante knowingly exploits.

Andrea Gazzoni's paper "Scores for a particular chemical orchestra: Reading Dante with Osip Mandelstam" focused on the network of music-based 
images through which the Russian poet Osip Mandelstam read the Commedia in his 1933 Conversation about Dante. Gazzoni tackles Mandelstam's independent, non-philological reading of Dante's poem as a way to explore sound and the imagery of sound as the most generative and visionary dimension of poetry.

"Dante vivo" was the title of Julia Bolton Holloway's talk, as well as a pedagogical project she directed in Florence. As a collaboration with the Ensemble San Felice, who performed the music of Dante's Commedia, this series of concerts held in Orsanmichele, Cologne, Avila, Graz, and Ravenna, was greatly successful. Bolton Holloway brought to life Dante's geography and history of his exile through music, journeying from the Babylonian cacophony of Hell's "Vexilla regis prodeunt" and from the tonus peregrinus of Psalm II3, "In exitu Israel de Aegypto," to the Ars nova polyphony of Verona and Ravenna. A DVD of this marvelous multimedia project illustrated the texts and made the music enjoyable to all.

Pedro Memelsdorff's presentation “'Che cosa è quest' Amor': Cavalcanti and Dante's Paradiso in a ballata by Francesco Landini" traced the connections between Dante's work and the music of Italian Duecento and Trecento. Memelsdorff considered a group of late fourteenth century musical compositions by Francesco Landini, Paolo da Firenze and Lorenzo Masini in relation both to each other and to Dante's Paradiso. Memelsdorff connected one of these songs, Landini's ballata "Che cosa è quest' Amor", to Guido Cavalcanti's "Chi è questa che ven ch'ogn'om la mira" and construed it as a response to the sonnet. Landini's setting transfigures Cavalcanti's Averroism in the light of Dante's cosmology, both hinted at through a web of textual allusions and correspondences. Moreover, Landini's ballata shares several features with some other texts related to Antonio Gherardi da Prato's Il Paradiso degli Alberti. Thus, the contextualization of "Che cosa è quest' Amor" within Gherardi's Paradiso may shed further light on the intellectual interaction between Landini and the philosophical circles of his time.

In "The Sensuous and the Asperous: Marenzio and Dante" Giuseppe Gerbino probed Luca Marenzio's unusual choice of a Dantean canzone (Cosi nel mio parlar voglio esser aspro) for a polyphonic madrigal. The light sensuousness of Marenzio's music coupled with Dante's deliberately harsh style makes this choice even more unique in a musical and literary panorama dominated by Petrarchism. Gerbino contextualized this search for asperity in the shifting interest in the values of a philosophically and morally high form of poetry that no longer had "piacevolezza" as its primary goal. Gerbino investigated the role of sound in the construction of poetic gravitas and the role of parlar aspro in musical language, also presenting Tasso's discussion of Dante's definition of poetry as "fictio rethorica musicaque poita" and Alessandro 
Guarini's identification of Marenzio with Petrarch and Luzzasco Luzzaschi with Dante.

Jess Tyre's talk, "Conversations with Francesca: Tchaikovsky, Liszt, and Wagner (and Zandonai and Granados and Rachmaninov) Go to Hell," profited from he intertextual connections of Tchaikovsky's Francesca da Rimini with Wagner's Ring of the Nibelung and Liszt's Dante Symphony to expand the critical discourse and discuss the intertextual dialogue Tristan und Isolde. Tyre established a "conversation" between Francesca's tale, as related in Dante's work and articulated through Tchaikovsky's and Liszt's music, and King Marke's speech at the conclusion of Act II of Tristan. The results suggest that these musicians shared a common language for projecting the story's narrative and for evoking its central emotions of desire, betrayal, guilt, and love.

David Heinsen ("Concerning Ugolino: Diverging Dante Aesthetics in Donizetti's Cantata") employed the depiction of Italy as a "literary construction" to discuss Gaetano Donizetti's i828 musical adaptation of Dante's episode of Count Ugolino (Canto XXXIII della Divina Commedia: Il Conte Ugoli$n o$ ). Heinsen distinguished the cantata's original intent from its critical reception, showing that the Italian Risorgimento transformed the poet's work from an aesthetic-literary phenomenon into one of political-ethical sacrosanctity. Heinsen proposed that Donizetti composed Ugolino with the intent of aesthetic preservation rather than politicization, and the speaker linked the differing frames of reference to their corresponding Dantean perspective in order to explain opposing views through the concept of codal interference: the obstructed communication of composer intent due to the Risorgimento's ideological recontextualization of Dante aesthetics.

Tekla Babyak ("Dante, Liszt, and the Alienated Agony of Hell") offered a musical analysis of Franz Liszt's Dante Symphony (I857), which expresses the loneliness of Dante's sinners, against the backdrop of the Romantic cult of solitude and its association with solitary contemplation, transcendence and ecstasy. On the contrary, Liszt's Dante Symphony rejects this position and reflects instead the horror of isolation. Babyak concludes that the Dante Symphony provides Liszt with an aesthetic framework for taking issue with the Romantic admiration for loneliness and artistic seclusion.

As a worthy conclusion of the first day, Italian pianist Leonora Armellini played Tre Sonate by Alessandro Scarlatti, Sonata Fantasy No.2 Op. Ig by Alexander Scriabin, Franz Liszt's Après une lecture de Dante and four compositions by Frédéric Chopin: Scherzo No. 2, Op. 3I, Souvenir de Paganini, Barcarolle $\mathrm{Op}$. 60 and Ballade No 4 Op. 52. Armellini regaled her audience with a truly exceptional concert, and her performance of Liszt's Dantean music also put into musical practice the importance of the theme of this conference. 
The second day of the conference opened with Alfred Crudale's paper, "'Canzone...t'ho allevata per figliuola d'Amore.' The Three Songs of Love in Dante's Vita Nuova." Crudale focused on three canzoni from the Vita Nuova, ("Donne ch'avete intelletto d'amore," "Donna pietosa e di novella etate" and "Li occhi dolenti per pietà del core") and illustrated how the poetics of musicality produces specific meanings by evoking the desired emotion in the reader. Crudale also linked Dante's canzoni to Guinizzellian and Provençal poems with a keen intertextual analysis.

Thomas Peterson's talk "From Casella to Cacciaguida: A Musical Progression Toward Innocence" acutely linked the musical performance of Amor che ne la mente mi ragiona in Pg. II to Cacciaguida's musical episode and to Dante's critical discussion of music's powers in the Convivio, with the constant presence of the planet Mars operating in all three texts. The ontological identification of Mars with music marks the pilgrim's moral and spiritual trajectory toward the eternal time of Cacciaguida's perspective.

Mirko Tavoni's "Poetry and Music in the De vulgari eloquentia" focused on the fabrilis quality of poesis in Dante's linguistic treatise. Tavoni examined three key passages that define the relationship between poetry and music, highlighting first the two components - verbal and musical - of poetry ("poetry is $[\ldots]$ a verbal invention composed according to the rules of rhetoric and music." DVE II iv 2). Tavoni then called attention to the preeminence of the poet over the musician ("no player of a wind or keyboard or stringed instrument ever calls his melody a canzone, except when it is wedded to a real canzone" DVE II viii 5), while stating that music becomes paramount for the genre of canzone because "every stanza is constructed harmoniously for the purpose of having a particular melody attached to it" DVE II x 2). Tavoni proposed to solve the apparent contradiction of Dante's argument by referring his notion of music allied to words in the DVE to a metrical notion, as stated by Boethian principles.

Karen Raizen's paper "Apostolo Zeno, Comedyphobe and Commediaphile" showed that, in keeping with the poetics of Arcadia, Zeno conceived of comic elements as separate from serious drama, distancing himself from the mixed style of baroque theater. Thus, despite his admiration for Dante apparent in his letters and his Biblioteca dell'eloquenza italiana (he also supported publications of De vulgari eloquentia and Monarchia), Zeno's position toward the Commedia was ambivalent and tended to exclude the stylistic coarseness of the Inferno. Raizen illustrated how Zeno's reading of Dante informed his ideas on genre and literary reform, as well as his libretti, particularly in relation to images of sublimity and 'comic' ascent.

In her talk "A Harsh Mistress: The Seconda Prattica and Monteverdi's Dantean Style," Aliyah Shanti laid bare the many Dantean references in Alessan- 
dro Striggio's libretto for Monteverdi's Orfeo, whose many references to the Commedia are often marked by musical highlights. Shanti showed that Monteverdi's very notion of seconda prattica, in which "the words are the mistress of the harmony," reflects the dichotomy between roughness, associated with the harsh sounds of Dante's Inferno, and elegance often likened to Petrarch's stylistic balance. Shanti argued that Monteverdi's use of Dante in Orfeo was a direct result of the poet's association with the seconda prattica and the musical innovations in the madrigals of the composer's predecessors.

In "'Dentro a la danza de le quattro belle': Dance in Dante's Commedia," Madison U. Sowell devoted critical attention to the representation of dance in the Commedia. Sowell looked into the allegorical roles of dance for the salvific experience, dwelling in particular on the Terrestrial Paradise pageant of "la danza de le quattro belle" (Purg. XXXI, I04), in which the cardinal virtues parallel the encounter with the three theological virtues, who are also "danzando al loro angelico caribo" ( $P g$. XXXI, I32). Sowell then linked these dances to that of the twenty-four wise spirits in Pd. XIII, 2O-2I, observing how all of these circular dance figures have the pilgrim at their center.

Carolyn T. Amory ("La Vita Nuova and Operatic Form") took cues from the Greek and then Roman concept of music as a force capable of affecting human thought and conduct. The medieval mind interpreted this concept through the Church's repression of "excessive emotion" in music, a position that Dante does not share in the Commedia, construing emotion in music as potentially positive. Amory then linked the Dantean musical expression of emotions with the evolution of recitative and aria, establishing an association between Dante and the early Opera of the Camerata de' Bardi and the Corsi group. These included Vincenzo Galilei (Galileo's father), TorquatoTasso, and Jacopo Peri (composer of the first opera). They all rediscovered ancient Greek melodic design based on verbal inflection and the resulting stile recitativo of Peri's Euridice ( 1585 ), to the lyrics by Ottavio Rinuccini, marked a new era in music. Amory then paralleled the alternation of prose and poetry in opera to the alternation of poetry and prose in Dante's Vita nuova.

Juliana Chapman ("From Dante's La Commedia to Monteverdi's L'Orfeo via Boethian musica") put emphasis on the interdisciplinarity of early opera as a musico-literary form and used Boethius's De institutione musica as a critical lens for analyzing the relations of text and music in Dante's Commedia and in Monteverdi's first opera Orfeo (1607), which bears the visible influence of Dante's masterwork. Chapman showed that Dante and Monteverdi had a shared perspective on classical Boethian music theory as both utilized it to create a series of explicit aesthetic moments that use the images and ideas of music, rhetoric, and poetry to shape musical and literary narratives of rhetorical interplay and unifying harmonic structure. 
Maria Ann Roglieri's talk "Dante's Commedia in Music: An Overview and Greatest Hits" focused on musical adaptations of Dante's masterwork, from the sixteenth century to the present. After a short but insightful overview of such musical compositions and their composers, Roglieri explored a selection of the most effective and acclaimed musical representations of all three canticles. These ranged across very disparate musical styles, places and times, and included Brazilian thrash metal band Sepultura and US rock band Alesana in addition to the more academically customary Jacques Charpentier, Franz Liszt and others. Roglieri's talk offered a fascinating survey of musical works inspired by Dante, showing how his poetry has been a constant reference point for musicians worldwide throughout the centuries.

Alex Cuadrado followed in a similar vein with his talk "Angels in the Architecture': The Case for a Dantean Framework in Paul Simon's 'You Can Call Me Al."' Cuadrado proposed to look at the journey of Paul Simon's song against the backdrop of Dante's journey and indicated some lines that seem reminiscent of Dante's Commedia, demonstrating how the song's three verses and their respective choruses line up with the three canticles of the Commedia. Moreover, at the center of "You Can Call Me Al," Simon recreates the dramatic climax of Purgatorio XXX, where Dante loses his first guide Virgil and Beatrice calls out his name. Cuadrado argued that this central vocative motif, also in Simon's song title, reverberates in the "Al" the song's title hinting to the poet's family name "Alighieri," while Beatrice's name becomes "Betty" in the song. A reference to Virgil's return to Hell would be adumbrated in the song as the protagonist's "role model" who "ducked back down the alley with some roly-poly little bat-faced girl."

Henry Martin's “Three Symphonies Based on the Purgatorio" presented his own Dante-inspired composition, a set of three symphonies dedicated to the Commedia's second canticle. Martin chose to present the second symphony, inspired by the central and longest section of the Purgatorio, in which the ascent through the terraces in the symphony's four movements is linked to the use of recurring motifs, a structural aspect that recurs in Dante's text. The format of entering a terrace, encountering instructive examples, interacting with one or more sinners, encountering further instructive examples, meeting an angel who chants a Beatitude and erases a P from Dante's forehead, then climbing to the next level repeats through all seven terraces. Martin envisioned these actions as the principal motives of Dante's climb and assigned a musical theme to each of those elements, so that each step in the ascent through the terraces would have a precise musical idea.

William Mahrt ("The Cessation of Music in the Paradiso") offered a final and insightful lecture on the interruptions of music and dance in Heaven. Mahrt explained these moments of quiet in the otherwise ever-performing 
universe as an anticipation of the ultimate point of the Paradiso, the vision of God as light, eternal and without motion. Since music is motion and is based on time, the final cantos where the pilgrim approaches the vision of God, the unmoved mover, must be without music. Mahrt framed his discussion in the context of Dante's use of music as an essential part of the narrative, in which musical types and antitypes characterize progress through the various stages of the Commedia. Mahrt recapitulated the musical progress through the Commedia from the noise of the Inferno through a progressive series of musical types to the cessation of music into silence.

This was the first conference specifically dedicated to Dante and music, a subject that has proven of great interest and extremely relevant for both a deeper understanding of Dante's works and an assessment of his enduring influence on the arts throughout the world. Special praise and thanks go to the organizers, whose efforts made this conference a rewarding and enjoyable experience for all the participants.

The full program can be found by following the link https://www.sas. upenn.edu/italians/event/20I5/II/dante-and-music. 